\title{
THE IMPLEMENTATION OF COMMUNITY ECONOMIC EMPOWERMENT PROGRAM (A Study in Nefonaek Village, Kota Lama Sub-district, Kupang City)
}

\author{
Olfenter H. Ledoh ${ }^{(1)}$; Petrus Kase ${ }^{(2)}$; Nursalam ${ }^{(3)}$ \\ Master Program in Administrative Sciences, Postgraduate Program, Universitas Nusa Cendana Kupang, East \\ Nusa Tenggara, Indonesia \\ Email: lerii1992@gmail.com
}

\section{ABSTRACT}

The aim of this study is to describe and analyze (1) the implementation of the Community Economic Empowerment Program (Pemberdayaan Ekonomi Masyarakat or PEM) in Nefonaek Village, Kota Lama Subdistrict, Kupang City and (2) the inhibiting factors in the implementation of that program. This study is a case study conducted qualitatively with the post-positivism paradigm as the research approach. It took place in Nefonaek, Kupang City with a consideration that the area is one of the recipients of PEM funds. This study focused on (1) the implementation of PEM funds and (2) the inhibiting factors in the implementation of PEM funds. A purposive sampling technique was used to determine the informants of the study. This study also collected primary data and secondary data as a source of data through observation, interview, and documentation. The data analysis was done based on the theory of Miles and Huberman (2007). Last but not least, the researchers checked the validity of the findings/conclusions by using a triangulation technique.

The results showed that the implementation of PEM in Nefonaek has not been going well; there are various gaps and issues in the environment. It is found that the standards and policy targets in the implementation of PEM were well-formulated but the standards in the use of PEM funds were often misused by the beneficiaries of the program.

Keywords: Policy, Implementation, Program, Empowerment, Community

DOI: $10.7176 /$ PPAR/11-1-06

Publication date: January $31^{\text {st }} 2021$

\section{BACKGROUND}

The policy of Kupang City Government to channel the funds for the Community Economic Empowerment Program (Pemberdayaan Ekonomi Masyarakat, abbreviated as PEM) is expected to increase the income of the community. One of the areas targeted for this program is Nefonaek where this village has been funded for PEM since 2013. The data showed that 240 Nefonaek residents received IDR 100,000,000.- to IDR 400,000,000.- each year. The number of funds received each year is varied, depending on the business of each beneficiary. The businesses in the village among others are grocery stores, photocopy centers, internet cafes, fish shops, greengroceries, workshops, barbershops, and etc.

The implementation of PEM program is the responsibility of Community Empowerment Institutions (Lembaga Pemberdayaan Masyarakat, abbreviated as LPM) at the village level. This village-level LPM consists of several elements such as Facilitator, Chairperson, Treasurer, and Administration Staff. These elements act as policy implementers; they are in charge of implementing and channeling PEM funds to assist the business of rural communities so that the income of the people can be increased, especially the people of Kupang City. For this reason, the role of LPM is very important to run the program in question.

It is hoped that PEM funds can increase the income and improve the business of the people in Kupang City. The repayment of PEM funds will be done in stages according to the size of the loan. To speed up the distribution of the funds, it is expected that the community can accelerate the payment of the loan. It is known that there still many residents who have not returned the PEM funds. Based on the author's preliminary observations, the total beneficiaries of PEM funds in Nefonaek were 176 people where 140 people had not returned the funds. In this case, the amount of the funds was IDR 150,000,000.- (LPM of Nefonaek, Kupang City 2018).

There were other problems in the implementation of the PEM program in Nefonaek. This made Nefonaek one of the villages in Kupang City that received a red card from the Kupang City Government.

The implementation of PEM in Nefonaek was not in accordance with the applicable regulations so that the implementation of this program was not optimal and resulted in program failure. The failure of PEM can be seen from the failed objectives; PEM was intended to alleviate poverty but quite the opposite, the poverty rate in Kupang City has increased in recent times.

Based on the data from the Central Bureau of Statistics (Badan Pusat Statistik, abbreviated as BPS), the number of lower-class society in Kupang City from 2014 to 2016 is as follows : 
Table 1. Lower-class Society in Kupang City

\begin{tabular}{|llll|}
\hline Year & Poverty Rate & Amount & Percentage (\%) \\
\hline 2014 & 413905 & 33.30 & 8.70 \\
2015 & 455927 & 39.73 & 10.21 \\
2016 & 482857 & 39.81 & 10.30 \\
\hline
\end{tabular}

Source: BPS of Kupang City (2017)

The table above illustrates the tendency of an increase in the poverty rate from 2014 to 2016 even though it has been intervened by PEM funds. The Kupang City Government believed that PEM can reduce poverty while in fact, this program has not achieved the expected goals. Weak assistance and supervision from LPM to the program and beneficiaries of funds as well as the lack of community participation lead to the underdevelopment of PEM fund activities. Many program beneficiaries were also in arrears to repay their loans. Due to this matter, Nefonaek became one of the 10 villages in Kupang City that received a red card from the Kupang City Government.

The objectives of this study are to describe and analyze the implementation of the PEM program in Nefonaek, Kota Lama Sub-district, Kupang City and its inhibiting factors. This study is also expected to have theoretical and practical uses. In terms of the theoretical uses, the results of this study can be used as a source of information for educational institutions that are useful for the development of science and technology in the Public Administration field. As for the practical uses, this study can contribute to the Kupang City Government, especially the Regional Development Planning Agency (Badan Perencanaan Pembangunan Daerah, abbreviated as BAPPEDA) of Kupang City, the Nefonaek Village Government, the LPM of Kupang City, and the people of Kupang City in general as a source of information and donation. Therefore, the findings in this study are expected to enrich the literature related to public policy. It is also hoped that this study can be used as a reference for other researchers to carry out further research in the same field.

\section{Public Policy}

\section{LITERATURE REVIEW}

When an issue that is in concern with common interests is deemed necessary to be regulated, the formulation of the issue becomes a public policy that must be carried out, formulated, and agreed upon by the authorized officials. When the public policy is set to be Law, Government Regulation, Presidential Regulation, or Regional Regulations, the public policy in question changes into law that must be obeyed.

Carl Friedrich (in Agustino, 2012: 7) defined policy as a series of actions/activities proposed by a person, group, or government in a certain environment where there are obstacles (difficulties) and possibilities (opportunities) by which the policy is proposed to be used as a solution to achieve the intended objectives. James Anderson (in Agustino, 2012: 7) also provided an understanding which says that public policy is a series of activities that have a specific purpose/goal, followed and carried out by an actor or a group of actors. This concept focuses on the things done rather than the things proposed or intended. This distinguishes policy with a decision; a decision is a choice among several alternatives. It is also said that public policies are decisions developed by government agencies and officials. As the special characteristic of public policy, David Easton (in Agustino 2012: 8) emphasized that policy is formulated by the authorities in the political system such as administrators, advisors, kings, and so on.

Based on the opinions of the experts above, it can be concluded that public policy is a series of activities or actions carried out by the government with specific aims and objectives, namely to overcome difficulties or problems that occur in the community. Nugroho (2004: 110-111) explained that the objectives of public policy can be distinguished based on its resources. Several public policies are aimed at distributing state resources and several public policies are intended to absorb state resources.

\section{Public Policy Implementation}

One of the important things in public policy is policy implementation. Implementation is often seen as merely a realization of what has been decided by the legislature or decision makers as if this process only had a little effect. In reality, policy implementation is crucial because a policy will mean nothing if it cannot be implemented properly. In other words, policy implementation is the stage where policy is implemented optimally to achieve policy objectives. This is based on the opinion of Chief J.O. Udoji (Agustino 2012: 140) that policy implementation is an important thing and even more essential than policymaking. A policy will simply be dreams or plans stacked to be archived if they are not brought into reality. In its principle, policy implementation is a way for a policy to achieve its goals.

Daniel Mazmanian and Paul Sabatier (Agustino 2012: 139) defined policy implementation as the fulfillment of basic policy decisions. Usually, it will be in the form of laws, important executive orders and decisions, or judicial decisions. Typically, this basic policy decision identifies the problem to be resolved and clearly states the 
goals or objectives to be achieved. A basic policy decision has various ways to structure or regulate the implementation process. Meanwhile, according to Van Meter and Van Horn (Agustino 2012: 139), policy implementation is the actions taken by individuals either by government or private parties to achieve the goals outlined in policymaking.

From here, it can be said that policy implementation is an activity of the policy implementers to distribute their political decisions to the target groups in an effort to achieve policy objectives. These policy objectives will not be achieved if there is no policy implementation. Even though the concept of implementation is often used to describe the efforts made by implementers in realizing policy objectives, simply mentioning implementation alone is not sufficient to describe it. In reality, the implementation itself contains a complex and long process.

\section{The Elements in Policy Implementation}

Tachjan (2006: 26) wrote that there are three absolute elements in policy implementation, namely Implementing Elements, Program, and Target Group. The implementing elements are the policy implementers. In this research, the implementing elements are the executors who proclaim the program. The second element in policy implementation is a program. According to Grindle (in Tachjan, 2006: 31), a program is a comprehensive plan. It portrays the resources needed and integrated the resources in one unit. A program contains goals, policies, procedures, methods, standards and budgets. In this study, the program implemented was the Three Moral Movements (Tiga Gerakan Moral) program consisting of the Return to Garden Movement (Gerakan Kembali ke Kebun), the Economic Living Movement (Gerakan Hidup Hemat), and the Safe Village Movement (Gerakan Desa Aman). Last but not least, there is a target group. Tachjan (2006: 35) reinforced that a target group is a group of people or organizations who receive goods or services that its behavior will be influenced by the policy.

\section{Factors Affecting Public Policy Implementation}

All public policies are intended to influence or control human behavior, persuading people to act according to rules or goals set by the government. If the policy cannot be fulfilled, or if the people continue to act in an unwanted way, or if the community does not carry out the prescribed methods, then the policy is said to be ineffective. In an extreme case, it can be said that the policy produces zero results. The factors that affect the implementation of public policy according to Agustino (2012: 157) are as follows:

a. The Determinants of Policy Compliance; (1) Respect for government authorities and decisions from the community; (2) The awareness of the community to accept the policy where the community is driven by rational choices. It is often found that the community is willing to accept and implement public policy as something logical, racial, and obligatory; (3) The existence of legal sanctions; (4) The existence of public interest; and (5) The existence of personal interests.

b. The Determinants of Policy Rejection or Postponement; (1) There is a policy that is contrary to the existing value system; (2) The lack of legal certainty; (3) The existence of a person's membership in an organization; and (4) The concept of non-compliance to the Law.

Rondinelli and Cheema (in Purwanto and Sulistyastuti 2012: 90) identified four factors that affect policy implementation, namely: 1) Environmental conditions; 2) Relations between organizations; 3) Resources; 4) Character of the implementer's institution.

\section{The Model of Policy Implementation Process from Donald Van Meter and Carl Van Horn}

Van Meter and Van Horn (1975) highlighted the importance of differentiating policy content because the effectiveness of policy implementation will vary greatly depending on the type and issue of the policy. The factors that influence the implementation process will also be very different. It is said that each policy needs different processes, structures, and relationships of different factors in its implementation. Van Meter and Van Horn also classified policies based on two main characteristics, namely the amount of change targeted by the policy and the amount of policy objectives acceptance from the implementing actors (Wahab, 1997: 79). The changes that are expected in policy implementation will have an impact on the organizational changes of the implementers. Winarno (2007: 155) assumed that this model not only determines the relationships between independent variables and dependent variables but also the relationships between independent variables. Van Meter and Van Horn believed that there are six variables as follows (in Winarno 2007: 156): (1) Policy objectives and measures; (2) Policy sources; (3) Communication between organizations and implementation activities; (4) Characteristics of the implementing agencies; (5) Attitudes/tendencies (disposition) of the implementers; as well as (6) Economic, social, and political conditions.

\section{The Approach to Overcome Policy Implementation Problem from George C. Edward III}

George Edward III (in Agustino 2012: 149) put forward four main issues for effective policy implementation in this following section: 
1. Communication

Effective implementation occurs when decision-makers know their next steps. Their knowledge can be useful if the communication runs well so that any decisions and regulations must be transmitted (or communicated) to the appropriate personnel. These are the three indicators that can be used in measuring the success of the communication: (a) good communication transmission, (b) clarity received by policy implementers, and (c) consistency of orders given in the implementation. In other words, the communication must be consistent and clear.

2. Resources

George C. Edward III (in Agustino, 2012: 149) clarified that resources are another important thing in policy implementation. This consists of several elements, namely: (a) Staff; (b) Information; (c) Authority; and (d) Facilities.

3. Disposition

The disposition or attitude of the policy implementer is an important factor in regards to the implementation of public policy. If the policy implementers want the policy implementation to be effective, they must know their steps and have the ability to realize it so that there will be no bias in the practice.

4. Bureaucratic structure

Complex policies require cooperation from many people. When the bureaucratic structure is not conducive to the available policies, this will make the resources ineffective and hinders policy implementation. The two factors that can boost the performance of a bureaucratic/organizational structure in a better direction are Standard Operating Procedures (SOPs) and Fragmentation (Edward III in Subarsono, 2011: 90-92).

\section{Community Empowerment Concept}

The implementation of a community empowerment program is a bottom-up model. This model usually deals with matters that are not directly related to national security such as contraceptive policies, superior varieties of rice, fishermen economic development, community empowerment program, and so on. Empowerment is an effort to improve welfare by encouraging, motivating, raising, and developing the awareness and potential of the community (Totok, 2000: 4). This is in line with the principle of the bottom-up model which includes all groups in every stage of the development process.

The empowerment of urban villages is directed to increase the people's economy productively so that it can produce high added-value and higher income. There are, at least, four things that affect the ability of the community to generate added value. This includes access to resources, access to technology, access to markets, and access to demand (Hutomo 2000: 3). In other words, empowerment means upgrading and making the poor independent. (Hutomo 2000: 4). The PEM program is intended to increase the community's economy productively so that it is able to generate high added-value and higher-income even though in reality, the objectives of this program have not been implemented optimally.

\section{Community Economic Empowerment Program}

The Community Economic Empowerment (Pemberdayaan Ekonomi Masyarakat, abbreviated as PEM) Program is intended to improve the economic structure of the community by providing business capital through PEM funds. The Kupang City Government is committed to build and empower the community, alleviating them from underdevelopment and poverty. The community empowerment in Kupang City is done in three ways. The first is by creating a healthy business climate and enabling the potential of community resources to be developed; secondly, strengthening the potential of community resources; and last but not least, preventing an unfair competition in the environment. PEM program is under the control of Kupang City Government and is technically under the coordination of BAPPEDA and other related Regional Apparatus Organization in Kupang City. Meanwhile, the operationalization of the management is left to the Community Empowerment Institutions (Lembaga Pemberdayaan Masyarakat, abbreviated as LPM) in each village.

PEM funds are intended to strengthen and develop the people's small-scale productive economic enterprises. This fund is sourced from the Regional Revenue and Expenditure Budget (Anggaran Pendapatan dan Belanja Daerah, abbreviated as APBD) of Kupang City in the form of grants to LPM which then will be distributed to the community. This fund is distributed for the development of productive economic enterprises and must be returned to the LPM treasury. Then, the fund will be allocated again for the community. 
The Organizational Structure of Fund Management in Nefonaek

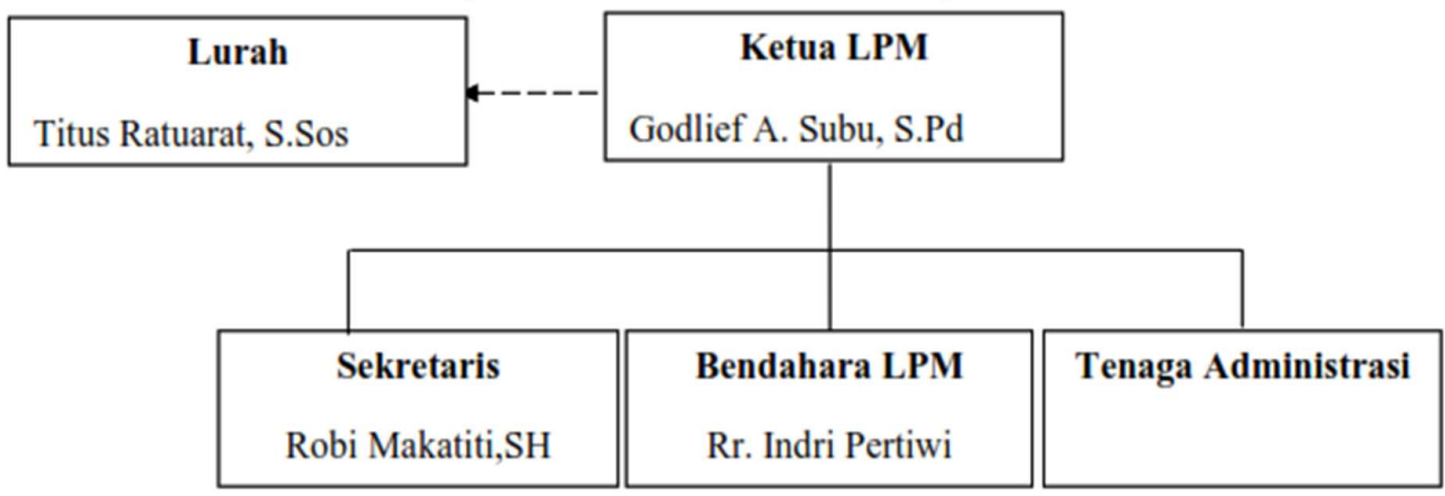

Source: Primary Data, 2019

Notes:

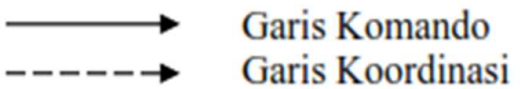

In order to optimize the distribution of PEM Funds on time, on target, on utilization, and in proper administration, a fund management team was formed in Nefonaek. The team consists of the Head of LPM, Secretary of LPM, and Treasurer of LPM. Meanwhile, the Administration Staff in this fund management team is local residents who meet certain requirements. Among those administrators, there are also Nefonaek Village Facilitator.

The success of a policy or regulation is very much determined by the implementation process. This makes policy implementation a vital stage in policy making. Therefore, the policy implementation of Kupang City Government to alleviate poverty through the PEM program in every area of Kupang City, which in this case is Nefonaek, becomes the researcher's concern to see the execution of the program that has been implemented from 2013 to the present. The implementation of the PEM program in Nefonaek has been carried out for 6 years. It can be seen that since the first year of launching, this program has had arrears in funds ranging up to hundreds of millions of Rupiahs. This happens due to many factors that hinder the implementation of the PEM program in Nefonaek. The activities carried out in this program are productive economic empowerment done by providing funds in the form of business capital. This is aimed to improve community economic institutions at the village level. The implementation of the PEM program is all detailed in the Decree of the Mayor of Kupang number 112D/KEP/HK/2017 concerning Guidelines of Utilizing Funds for Community Economic Empowerment in Kupang City.

\section{RESEARCH METHODS}

This paper is a case study that was done qualitatively with the post-positivism paradigm. This study was conducted in Nefonaek Village, Kupang City as one of the villages that received the PEM program. The focus of this study was the implementation of PEM funds which contain several sub-focus such as (a) socialization; (b) assistance; (c) participation; and (d) supervision. Furthermore, this study also focused on the inhibiting factors of PEM funds implementation with a number of sub-focus such as (a) policy standards and objectives; (b) resources; (c) communication between organizations; (d) the attitude of the implementers; (e) the characteristics of the executing agents; and (f) social, economic, and political conditions. The informants in this study were determined using purposive sampling techniques. Primary data and secondary data were used as the source of data in this study. The data were collected through observation, interviews, and documentation. The data analysis was performed based on the theory of Miles and Huberman (2007). In the final stage, the validity of findings/conclusions was checked using triangulation techniques.

\section{RESEARCH RESULTS}

\section{The Implementation of PEM Program in Nefonaek, Kupang City}

It is found that there were arrears in the repayment of PEM funds from 2013 to 2018. The arrears in 2013 were $9.90 \%$ where this number increased by up to $54 \%$ in 2017 . Until today, there still some burdens in the repayment of this fund. Within the 6 years of implementation, it is noted that 57 people of the 240 beneficiaries $(23.75 \%$ ) of PEM funds in Nefonaek still have arrears. 
Based on the results of the study, the revolving funds distributed in the last 6 years of PEM implementation were IDR $1,462,000,000$.- with an installment of only $9.90 \%$. It is reported that the highest amount of arrears occurred in 2018; 38.46\% of PEM funds still in the hands of Nefonaek people.

To obtain these funds, there are stages and mechanisms that must be taken by the people of Nefonaek. This starts with a proposal submission to the LPM of Nefonaek. The prospective beneficiaries of PEM funds need to prepare documents such as application letters to the Head of LPM under the recommendation of the Neighborhood Head (Ketua RT) and Village Head (Lurah). After that, the proposals or application letters submitted by the community are checked and selected by the Managers of PEM Funds and the Head of LPM to enter the administrative and factual verification as well as re-verification. Then, the results of reverification from the technical and expert teams are submitted to the Head of LPM and the Managers of PEM Funds as a material of consideration to determine the prospective beneficiaries. In summary, the determination of PEM funds' beneficiaries begins with the proposal verification and re-verification from LPM, Managers of PEM Funds, and Neighborhood Head where the event is attended by technical and expert teams. The fund beneficiaries are determined by a Decree from the Head of LPM of Nefonaek with a maximum amount of IDR 25,000,000.- (twenty-five million Indonesian Rupiah).

In the next stage, there is a PEM Funds Disbursement Stage. The Head of LPM of Nefonaek submits an application to the Mayor of Kupang City by attaching a Decree presenting the beneficiaries of PEM Funds. Furthermore, the Head of LPM of Nefonaek opens an account at Bank NTT using the Nomenclature of Nefonaek Village and is signed by the Head and Treasurer of LPM as well as the Village Head of Nefonaek. Before disbursing funds to PEM Fund beneficiaries, LPM makes a joint agreement between LPM and PEM Fund beneficiaries regarding the number of funds to be returned every month. Then, the LPM of Nefonaek will immediately distribute funds to PEM Fund beneficiaries no later than 7 (seven) days after the funds are disbursed by the Kupang City Government to the LPM bank account. The total of the fund is in accordance with the amount contained in the decree. If the fund is above IDR 5,000,000.-, it will be deposited into the beneficiary's account but if the fund is under IDR 5,000,000.-, it will be given to the beneficiary in cash.

After the funds are received, the beneficiaries are given an opportunity to run the business in the first three months without having to return the funds/loans so that they can focus on the business. Nevertheless, entering the fourth month, they have to pay the basic loan periodically to the LPM of Nefonaek. The beneficiaries pay their loans to the LPM account and the proof of their payment is submitted to LPM through the Manager of PEM funds. The funds that have been returned to the LPM account are rolled back to the community based on the proposal or application letter submitted by the community. The proposal itself still needs verification and re-verification from the administrators. This fund redistribution is carried out if the repayment of LPM installments has reached a minimum of $25 \%$ from the PEM funds used. The interest of the funds will be used as additional capital for the people of Nefonaek.

The problems that arise in the implementation of this policy will affect the receipt of funds that do not meet the predetermined targets. The researchers have found several stages that are considered important for the implementation of the PEM program in Nefonaek, Kupang City such as:

\subsection{Socialization}

Socialization is an effort to advance something. In this case, socialization is an effort to provide information related to the PEM program for all people of Nefonaek. The socialization of the PEM program is intended to provide awareness and understanding to the community regarding the aims and objectives of the program and the mechanisms to get financial assistance from the beginning to the end of the program. In order to provide good output and outcome, program socialization should be carried out regularly and periodically so that the community can understand the PEM program clearly. This will prevent a failure in the program implementation. The frequency of socialization is very important to introduce a program. In other words, it can be said that frequent socialization will build a better understanding and awareness of this PEM program.

Based on the results of the study, it is revealed that socialization, which is the most important part of program implementation, was not carried out in a planned and periodic/routine manner to the community. This means that the dissemination of information and awareness to the community regarding the PEM program implemented in Nefonaek is still poor. The lack of socialization is highly influential in the success of this program.

\subsection{Assistance}

Assistance is one of the factors that will greatly assist the community as the recipient of the program. Likewise, the implementation of the PEM program will be more effective and efficient if the program is assisted by the LPM of the village so that the community can run its productive economic enterprises optimally. 
The results showed that in the implementation of the PEM program, there was no assistance from the LPM of Nefonaek to develop the economic enterprises of the people. In fact, many people said that they have never received assistance from LPM regarding their efforts to develop productive economic enterprises. It can be pulled into the conclusion that in this PEM program implementation, the assistance to develop the business of the people is not going well.

\subsection{Community Participation}

Community participation is one of the important elements of program implementation. Implementers as policy implementers and the community as program recipients have a key role in this matter. They need to be actively involved so that a program can run well. In relation to the implementation of the PEM program, the community as program recipients is also required to be actively involved. Their economic enterprises must be well developed; they also need to pay the monthly installments for 18 months routinely. This is the most important part of community participation in the implementation of the PEM program.

The results of the study proved that the 18 months installments have run well. Many people were found to be active in paying their loans. However, several people still experienced obstacles in paying their installments because their businesses faced some problems. This can be seen from the rate of arrears in Nefonaek from 2013 to 2018.

\subsection{Supervision}

In a program implementation, supervision is a process of observing, checking, and correcting rather than the implementation of all organizational activities to ensure that all work/activities are carried out in accordance with the predetermined plan. In relation to the implementation of the PEM program, supervision from LPM to the community is necessary to be done. If there is no supervision, the community as business owners and beneficiaries of the PEM program are at risk to make mistakes in the program implementation.

To sum up, the supervision in the implementation of the PEM program is still lacking. The community admitted that they had never been visited by the LPM, although in the Implementation Guidelines (Petunjuk Pelaksanaan, abbreviated as JUKNAS) and Technical Instructions (Petunjuk Teknis, abbreviated as JUKNIS), LPM was obliged to supervise the development of community economic enterprises.

\section{Inhibiting Factors}

To measure the success of community economic empowerment program implementation in Nefonaek, Kupang City, the researchers used a policy implementation model from Van Meter and Van Horn (1975: 463). They analyzed the inhibiting factors of program implementation with 6 indicators, namely; (1) policy standards and objectives; (2) resources; (3) communication between organizations and its strengthening activities; (4) characteristics of the executing agents; (5) social, economic and political conditions; and (6) the implementer disposition.

\subsection{Policy Standards And Objectives}

Since this policy was initiated in Nefonaek from 2013 to 2018, as many as 168 target groups had registered as fund beneficiaries. The results of this study pointed out that the standards and targets of this empowerment program have been implemented quite optimally. Referring to the Decree of the Mayor of Kupang number 112D/KEP/HK/2017 concerning Guidelines of Utilizing Funds for Community Economic Empowerment in Kupang City, the standard in the implementation of the PEM program is the strengthening and development of productive economic enterprises targeted at individual businesses. In its implementation, the LPM of Nefonaek already attempted to follow the objectives of the program but there were some communities that used the funds for other purposes; they did not allocate the funds to develop their productive economic enterprises.

\subsection{Resources}

In this study, the resources used for the implementation of the PEM program in Nefonaek are human resources, funds/loans, and work facilities. As for the human resources, there was the Head of Nefonaek Village, Head of LPM, Secretary of LPM, Treasurer of LPM, and Administrative Staff of LPM. It is assumed that all of them are capable to implement the PEM program due to their level of education and experience that is equivalent to a Bachelor Degree. The quality of the funds/loans is also considered good because the budget continues to be prepared by Kupang City Government. In terms of the working facilities, Nefonaek does not have adequate facilities so that it complicates the work of LPM. 


\subsection{Communication between Organizations and its Strengthening Activities}

This study clarifies that the coordination between organizations was carried out once a month by Regional Apparatus Organization such as BAPPEDA and the Mayor of Kupang. The coordination also often took place at the village level with the Village Head as the village supervisor. Whereas, there is no coordination between village officials and the board of village empowerment. This should be done by the LPM of Nefonaek as the responsible implementer of this program. Looking at the technical instructions of the Mayor of Kupang stipulated in the Decree number $112 \mathrm{D} / \mathrm{KEP} / \mathrm{HK} / 2017$ concerning Guidelines of Utilizing Funds for Community Economic Empowerment in Kupang City, coordination with the board of village empowerment must be done so that there is harmony in the implementation of PEM program. Meanwhile, LPM as a program implementer neglects the role of the village empowerment board as the responsible party in this program.

\subsection{Characteristics of the Executing Agents}

The characteristics of the executing agents of the PEM program in Nefonaek can be said to be good as it has achieved efficiency in terms of staff size. The researchers observed that the LPM of Nefonaek has good quality seen from the level of education and work experience.

\subsection{Social, Economic, and Political Conditions}

The researchers accounted for that social, economic, and political conditions contribute to the success of this program implementation. This was indicated by the economic resources in the jurisdiction or implementing an organization that is sufficient to support the implementation of this policy. It is known that the budget allocation for this program is always increased each year. A conducive social environment is also able to increase the economic level of the community. This will have an impact on increasing the social status of the community. Fortunately, there is no opposition from the political elites even though this program is a continuation program from the previous reign. The only problem in this matter is public holidays. During public holidays, several photocopy and printing centers must have more capital to keep their business running.

\subsection{Implementer Disposition}

In regards to implementer disposition in the implementation of the PEM program in Nefonaek, it is known that the response of the implementer to run the program is already good. Nevertheless, the implementer sometimes becomes apathetic in the program implementation. The researchers discovered this problem when they conducted observations at the LPM of Nefonaek. Some administrative staff often absent during service hours; be noted that the service hours of the institution are from 08:00 to 16:00. Oftentimes, they were not at the office during that service hours. As for an example, the researchers had made an appointment for an interview at the office a week earlier but after for 4 consecutive days, the administrative staff were never present. Therefore, the interview was carried out at the informant's house.

\section{CONCLUSION}

1. In conclusion, the implementation of the Community Economic Empowerment Program (Pemberdayaan Ekonomi Masyarakat or PEM) program in Nefonaek Village, Kupang City is still poor because of various issues that have occurred in the implementation, such as (1) the lack of socialization from Community Empowerment Institutions (Lembaga Pemberdayaan Masyarakat, abbreviated as LPM) to the people of Nefonaek to help provide information and awareness related to the PEM program; (2) the lack of assistance from the implementers of the PEM program, causing the community to experience difficulties in running economic businesses; (3) the low community participation in paying routine installments leads to arrears even though several people are already active in paying their installments; and (4) the lack of supervision from LPM where the community is not properly supervised by LPM in running the business.

2. There also a number of inhibiting factors in the implementation of the PEM program. The first is in relation to policy standards and targets. The policy standards and targets have been well formulated by the concerning parties but the funds were often misused by the beneficiaries of the funds. Besides that, the work facilities of LPM for the implementation of this program are still inadequate. The communication between the village government and organizations is already in compliance with the guidelines from Kupang City Government but the communication between the empowerment board and the LPM of Nefonaek is not going well. On the one hand, the characteristics of the executing agents in terms of supervision and competence are already good. In terms of the social factors, several photocopy and printing 
centers experience difficulties during public holidays. The disposition of the implementer that runs this program is also not conducive. It is found that the administrative staff of LPM in Nefonaek often not present during service hours.

\section{SUGGESTION}

1. To optimize the management of PEM funds to be effective and right on target, it is necessary to increase the socialization of the PEM program so that the community will not be mistaken in the use of these funds. The facilities and infrastructures in the LPM of Nefonaek also need to be improved. Besides that, it is essential to build good communication between the LPM and the Board of Community Empowerment in Nefonaek so that the program can be in harmony. Not forget to mention that it is important to improve the awareness of LPM administrators to make them work in an orderly manner.

2. It is crucial to increase the supervision for the management and receipt of PEM funds. This can be done in stages starting before the policy is implemented. When the policies are implemented, they should be monitored routinely. It is important to keep control to find out the weaknesses in the implementation so that the policies will be right on target, efficient, and precise.

3. Awards and strict sanctions to policy implementers and communities also significant for this program implementation. In other words, achievements must be appreciated and mistakes should be followed by strict sanctions. With the giving of rewards and sanctions, it will create healthy competition between policy implementers and the community in each village. This will motivate the concerning parties to keep on innovating for this program.

\section{BIBLIOGRAPHY}

1. Agustino, Leo. 2012. Dasar-Dasar Kebijakan Publik. Bandung, Alfabeta.

2. Nugroho, Riant. 2004. Public Policy (Dinamika Kebijakan- Analisis Kebijakan Manajemen Kebijakan). Jakarta, Media Komputindo.

3. Tachjan. 2006. Implementasi Kebijakan Publik. Bandung, AIPI.

4. Purwanto, Agus Erwan dan Sulistyastuti, Dyah Ratih. 2012. Implementasi Kebijakan Publik. Konsep dan Aplikasinya di Indonesia. Yogyakarta, Gava Media.

5. Van Meter, Donal dan Van Horn, Carl E. 1975. The Policy Implementation Process Conceptual Frame Work. Journal Administration and Society.

6. Wahab, Solichin Abdul. 1997. Analisis Kebijakan: dari Formulasi ke Penyusunan Model-Model Implementasi Kebijakan Publik. Jakarta, PT Bumi Aksara.

7. Winarno, Budi. 2007. Kebijakan Publik, Teori, dan Proses. Media Press, Yogyakarta.

8. Subarsono. 2011. Analisis Kebijakan Publik (Konsep, Teori, dan Aplikasi). Yogyakarta, Pustaka Pelajar.

9. Totok, Mardikanto. 2000. Konsep-konsep Pemberdayaan. Surakarta, PT Rafika Aditama.

10. Hutomo, M. Yatmo. 2000. Pemberdayaan Masyarakat Dalam Bidang Ekonomi. Yogyakarta, Adyana Press

11. Miles, Mattew B dan Amichael Huberman. 2007. Analisis Data Kualitatif Buku Sumber tentang Metode-Metode Baru. Terjemahan Tjetjep Rohendi Rohisi. Jakarta, Universitas Indonesia. 